\title{
Urban and future climate - Impact on energy consumption and thermal comfort of buildings
}

\author{
Jan Remund ${ }^{1}$ and Urs Grossenbacher ${ }^{2}$ \\ ${ }^{1}$ Meteotest AG, Bern, Switzerland \\ ${ }^{2}$ Pronoo AG, Givisiez, Switzerland
}

\begin{abstract}
Climate change and the urban heat effect are expected to have a large influence on the energy consumption and thermal comfort of buildings. However, using meteorological data which incorporates effects of climate change and characteristics of cities (e.g. vulnerability to the 'urban heat island' phenomenon) is not currently a standard practice in building simulation (BPS).

By default, typical meteorological years based on meteorological data of the past 20 years of nearby meteorological stations are used. These stations are normally located outside the city centres (e.g. at airports). From this follows that neither climate change nor urban effects are taken into account in building performance simulation. This may lead to important discrepancy between simulation results and real energy consumption and/or indoor climate data for buildings in urban areas and under future climate conditions.
\end{abstract}

Within Climate-fit.city, these effects are analysed. In a first step, adapted urban and future climate data (modelled with the UrbClim model by VITO) and standard (non-adapted) climate data were compared by analysing the distribution of hourly mean outside temperature for one year. In a second step, this data were included within the Meteonorm software. This will enable the software to model the urban and climate change effects for any place within the urban areas. In a first edition, this was made for the cities of Bern, Prague, Barcelona, Vienna and Rome. In the future, this data will be included for other urban areas in Europe.

In a third step the urbanized TMY data sets generated by Meteonorm were used to simulate energy consumption (heating, cooling) and indoor climate conditions (operative temperature) with models of several typical buildings. The whole year simulation runs were made in series for several urban locations and - as reference scenario - with the standard TMY. The "urban" and "future" results were then compared with the reference scenario.

Climate-fit.city is a EU project in the framework of Horizon 2020.

\section{Introduction}

The purpose of the project is to develop services to provide building design engineers more accurate and adequate climate data for simulating buildings located in cities. The objective is to construct/refurbish buildings with better indoor quality and less energy demand.

For the Building Energy service, Meteotest enhances its Meteonorm software and web service to account for urban climate conditions, in particular the urban heat island effect, using high resolution climate data of Urbclim model. Concretely, this enables the stochastic generation of time series of a so-called Typical Meteorological Year (TMY), as well as extreme (hot/cold) years, both for the current situation and under future climate conditions.

The first phase equals to the test phase of urbanized Meteonorm (Meteonorm Version 7.3 / MN 7.3). Pronoó employs urbanized Meteonorm data to simulate building cooling and heating loads and thermal comfort levels using the IDA-ICE building simulation software. The results are compared to simulation results based on standard TMYs.

The objective of the first phase is to show low deviations at sites with met stations used to produce standard TMY (the data used historically for building design) and to prove the working hypothesis that for sites within cities, significant deviations are seen compared to the standard meteo stations (and therefore urban adaptation is needed).

In the second "replication" phase, more cities in Meteonorm will be upgraded with urbanized data. The final target is to include urbanized Meteonorm data for all bigger urban areas in Europe and in other continents and like this to enable more accurate building performance simulations for urban locations.

\section{Used data \& methods}

VITO delivered ERA-5 (2010-16) and ERA-Interim (1987-2016) based UrbClim NetCDF files for the selected cities in hourly time resolution. ERA-5 and ERA-Interim are re-analysis datasets of ECMWF. They include gridded fields of meteorological parameters for historical periods. Urbclim (De Ridder et al., 2015) is a fast urban boundary layer climate model.

Parameters used were temperature, wind speed, relative humidity, global radiation (directly from ERA5/Interim) and precipitation (directly from ERA5/Interim - and not used for modelling).

Based on the input values Meteotest calculated TMY based on Sandia method and condensed the temperature information into Meteonorm. The results of Meteonorm 
were TMY datasets in hourly input format for IDA-ICE. This includes the parameters air temperature, relative humidity, wind speed, wind direction, direct horizontal radiation and diffuse horizontal radiation. In Figure 1, the data flow of the production of the TMY's is shown.

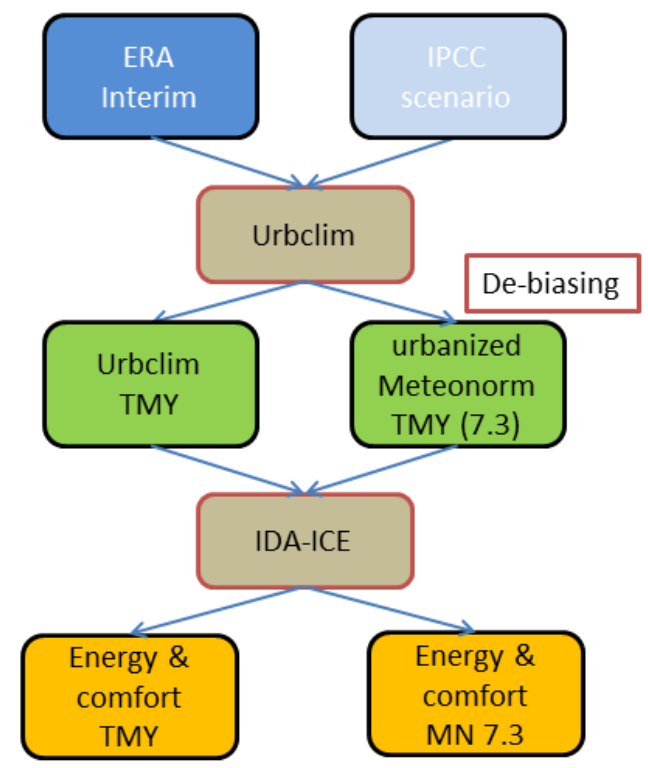

Figure 1: Data flow of TMY production.

Measurements were used to compare the results and for debiasing. The stations are from MeteoSwiss for Switzerland and Zentralanstalt für Meteorologie und Geodynamik (ZAMG) for Austria. Bern/Bollwerk is a station from Swiss National Air Pollution Monitoring Network.

\section{Condensing UrbClim Output into "urbanized" Meteonorm}

Starting points for condensing UrbClim output into "urbanized" Meteonorm are ERA/UrbClim high resolution fields calculated by VITO. For making TMY datasets as well as input data for urbanized Meteonorm, 20 years of hourly data are needed.

In a preliminary step, ERA-5 and -Interim based datasets were bias corrected. This was done by defining the difference of the yearly average temperature and the factors of wind speed and global radiation at the site of the official meteo station for Bern and Vienna (Bern/Zollikofen; Wien/Hohe Warte) for the period 2010-16. The correction values were then applied to the whole modelled grid (Table 1).

Table 1: Bias corrections for Bern and Vienna for ERAInterim.

\begin{tabular}{|c|c|c|c|c|}
\hline Site & $\begin{array}{c}\text { Tempe- } \\
\text { rature } \\
{\left[{ }^{\circ} \mathbf{C}\right]}\end{array}$ & $\begin{array}{c}\text { Wind- } \\
\text { speed } \\
{[-]}\end{array}$ & $\begin{array}{c}\text { Precipi- } \\
\text { tation } \\
{[-]}\end{array}$ & $\begin{array}{c}\text { Global } \\
\text { rad. } \\
{[-]}\end{array}$ \\
\hline $\begin{array}{c}\text { Bern/ } \\
\text { Zollikofen }\end{array}$ & $1.4^{\circ} \mathrm{C}$ & 1.00 & 1.0 & 1.076 \\
\hline $\begin{array}{c}\text { Wien/Hohe } \\
\text { Warte }\end{array}$ & $0.0^{\circ} \mathrm{C}$ & 0.75 & 0.9 & 1.000 \\
\hline
\end{tabular}

Meteotest condensed the bias corrected fields on a regular grid $(1 \mathrm{~km}$ at the outer area of the cities, $250 \mathrm{~m}$ within the cities) to TMY and input data for the Meteonorm stochastic temperature model. At this stage, higher resolutions (e.g. $100 \mathrm{~m}$ ) haven't been included as the data volume and calculation time would have been too big.

Temperature distributions of 450 locations have been saved for Bern and 950 for Vienna. For Bern 9 additional test locations were modelled and 5 for Vienna (Figure 4). Those were used for comparing the building simulation results.

Figure 4 show also that the topographies in Bern and Vienna are rather complex; both lay next to a river (Aare and Danube) and at the foothills of the Alps.

TMY generation, directly based on ERA/UrbClim data, was used as an intermediate step. They have also been benchmarked along the urbanized Meteonorm data. TMY were calculated based on Sandia Method described by NREL (Wilcox and Marion, 2008).

Preliminary tests with other methods (prEN ISO 159274:2005, https://www.iso.org/standard/41371.html) did show clearly lower accuracies and were therefore not used.

In Meteonorm, a Markov chain model (Remund et al. 2018) is used to generate daily temperature values. This model is based on temperature distribution from meteo stations (approximately 6000 stations). To get urbanized Meteonorm temperature, distributions of approx. 400 input sites per cities from ERA/UrbClim models were added (at the points in Figure 1 and Figure 2). The following temperature parameters are used as statistical values for the model:

- Monthly distribution of the daily temperature with 7 points of the monthly distribution are stored $(1 / 31$, $3 / 31,6 / 31,15 / 31,25 / 31,28 / 31,30 / 31$ quantiles)

- Monthly mean temperature

- Monthly mean of daily minimum and maximum hourly temperatures

- Mean monthly minimum and maximum hourly temperatures

- Mean standard deviation and difference of day to day variation, separated for days below and above the average daily difference between maximum and minimum temperatures. This approximately corresponds to a separation into clear and overcast days or days with high and low radiation

- Mean minimum daily temperature per year

- Mean 4 day minimum temperature per year

- Mean maximum daily temperature per year

- Minimum and maximum hourly value per month of all 10 years

- Monthly deviation of average temperature in relation to meteo station (e.g. Zollikofen for Bern area); values are adapted for altitude differences

For sites within a city a general urban heat effect value of $1^{\circ} \mathrm{C}$ is assumed in Meteonorm. The last bullet point is new and is used to correct the standard yearly urban heat 
effect value. At the new data points, the urban heat effect is corrected to the local level.

\section{Validation of urban TMY}

A first test based on urbanized Meteonorm (MN 7.3) was done by comparing the climate datasets with measurements at meteo stations. Data TMY directly made of ERA/UrbClim time series (ERA 5 / ERAInterim), SIA 2028 (http://www.energytools.ch/index.php/de/, 1984-2003, the default TMY in Switzerland for building design), Meteonorm 7.2 (last version), Meteonorm 7.3 and measurements were listed.

All datasets aside SIA 2028 have been adapted (bias corrected) to Zollikofen (that's why all show low deviations for Zollikofen). SIA 2028 show somewhat lower temperature values due to the older period (19842003).

The urban effect between Bollwerk, Von Roll and Zollikofen is about $1{ }^{\circ} \mathrm{C}$ (measured as well as modelled). ERA 5 and ERA-Interim underestimate the urban heat effect, whereas Meteonorm shows the same magnitude. For Vienna ERA and MN overestimate the urban effect somewhat (measured: $1.1^{\circ}$, ERA: $1.7^{\circ} \mathrm{C}, \mathrm{MN}: 1.9^{\circ} \mathrm{C}$ ).

Also, different temperature thresholds have been checked (like tropical nights, hot days and maximum temperatures). In table 2 and 3, the number of hot days (daily maximum above $30^{\circ} \mathrm{C}$ ) are listed as an example of temperature threshold values.

Table 2: Number of hot days 3 sites with measurements in Bern.

\begin{tabular}{|c|c|c|c|}
\hline Model & $\begin{array}{c}\text { Bern/ } \\
\text { Bollwerk }\end{array}$ & $\begin{array}{c}\text { Bern/ } \\
\text { Zollikofen }\end{array}$ & $\begin{array}{c}\text { Bern/ } \\
\text { Von Roll }\end{array}$ \\
\hline ERA 5 / UrbClim & 5 & 2 & 2 \\
\hline ERA-Interim / UrbClim & 3 & 1 & 5 \\
\hline SIA 2028 (TMY) & & 0 & \\
\hline MN 7.2 & 4 & 3 & 3 \\
\hline MN 7.3 & 5 & 5 & 3 \\
\hline Measured & 12 & 9 & 14 \\
\hline
\end{tabular}

Table 3: Number of hot days for 3 sites with measurements in Vienna.

\begin{tabular}{|c|c|c|c|}
\hline Model & $\begin{array}{c}\text { Wien/ } \\
\text { City }\end{array}$ & $\begin{array}{c}\text { Wien/ } \\
\text { Hohe Warte }\end{array}$ & $\begin{array}{c}\text { Wien/ } \\
\text { Unterlaa }\end{array}$ \\
\hline ERA 5 / UrbClim & 9 & 2 & 2 \\
\hline ERA-Interim / UrbClim & 16 & 11 & 12 \\
\hline TMY ZAMG (TMY) & & 7 & \\
\hline MN 7.2 & 13 & 7 & 9 \\
\hline MN 7.3 & 19 & 12 & 16 \\
\hline Measured & 30 & 24 & 23 \\
\hline
\end{tabular}

Validation of Climate Change forecasts (TMY)

A second test based on urbanized Meteonorm (MN 7.3) was done by comparing climate datasets with climate change forecasts. The future tests included for the cities of Bern, Rome, Barcelona and Prague.

Equation 1 shows the method to calculate future average monthly temperatures:

$$
\begin{aligned}
& \begin{array}{l}
T T_{2046-55}=T T_{2000-09} \\
+\left(T T u b_{2046-55}-T T u b_{1986-2015}\right)
\end{array} \\
& +\frac{\left(T T_{\left.1986-2015-T T_{2000-09}\right)}\right.}{+(1)}
\end{aligned}
$$

where TTx are measured temperatures and TTub are modelled temperatures from UrbClim. The same average values of the differences are used for all points to correct the climate change between 1986-2015 and 2000-09.

This includes a compensation of the average yearly difference between the periods of 1986-2015 (UrbClim) and 2000-09 (Meteonorm) to use the correct base period. The corrections are small: for Bern $-0.45^{\circ} \mathrm{C}$, for Vienna and Prague $-0.25^{\circ} \mathrm{C}$ and for Barcelona and Rome $0^{\circ}$.

Four models have been used:

- temperature distributions based on RCP 4.5 / 8.5 (2046-55) grid points downscaled with UrbClim

- For Bern, also B1 and A2 scenarios based on IPCC AR4 included in MN 7.3 for 2050 were compared; additionally the time period 2045-74 (2070) has been investigated

Differences between centre and land (heat island effect) aren't very high concerning average temperatures (in the range of $\left.0.8-1.5^{\circ} \mathrm{C}\right)$. Changes concerning climate change are higher $\left(1.8-2.2^{\circ} \mathrm{C}\right.$ for RCP 4.5 and $2.5-2.8^{\circ} \mathrm{C}$ for RCP 8.5 ). The combination of both effects can reach more than $4^{\circ} \mathrm{C}$.

Maximum temperatures do differ only slightly between centres and land. On average, they are even lower in the centres as in the surrounding. An exception is Barcelona, where the airport station is located also nearby the sea (which has a lowering effect for maximum temperatures). Differences regarding climate change are much higher $\left(4.7-7.4^{\circ} \mathrm{C}\right)$. They are also more than twice as high as for average temperatures. The models show bigger trends of maximum temperatures in the cities.

In most cities (aside Rome) there are clearly more tropical nights in the city centre (5-57 days). Again, in Barcelona the sea has a clear influence on the Airport. Climate change has a slightly higher effect than the built environment. By 2050, in the northern sites outside city centres tropical nights will occur regularly (up to now they were seldom). Differences between city centres and surrounding are getting smaller in future.

Hot days do not show big differences between city and land (with exception of Barcelona, which includes sea/land effects), whereas climate change has a big influence (13-47 more hot days) - especially in the South (Barcelona and Rome), where hot days may be doubled in future.

It's clearly visible that future climate changes are big much bigger than differences within the city or compared to the surrounding land. Climate change till 
2050 (2046-75) will be $1.5^{\circ} \mathrm{C}$ for RCP 4.5 and $2.5^{\circ} \mathrm{C}$ for RCP 8.5. The difference between urban and land is getting somewhat lower in future (the reason for this isn't known).

Figure 2 shows the daily profile for summer periods for Bern/Zollikofen for scenario RCP 8.5 (2050). The difference to the current climate is clearly visible.

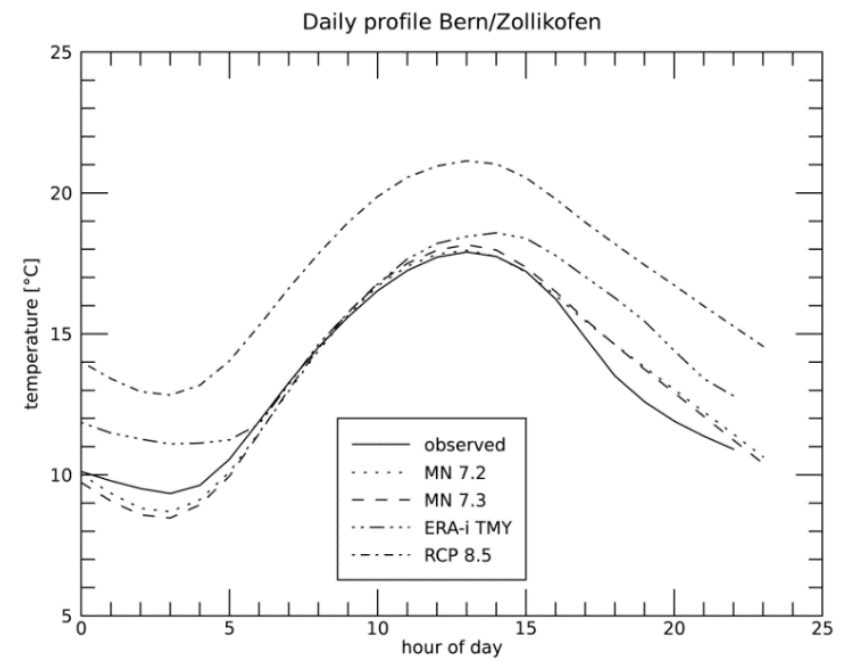

Figure 2: Mean daily temperature profile during summer half year for Bern.

Differences compared to current global IPCC AR4 scenarios built in MN 7 are significant. Warming trends are slower in IPCC AR4.

\section{Testing of new climate data}

Pronoó defined (up to now) one type of building (multifamily house), using two building standards (historic of 1960 - 79 and current of >2006). In series of full years simulations, the energy consumption (heating and cooling) and the indoor climate (EN-15251: typical hours per year in four comfort classes) for the different buildings and climate files were compared for Bern, Vienna, Prague, Barcelona and Rome.

\section{Simulation models and boundary conditions}

A simple standard-building body with typical urban shading situation has been defined (Figure 3). According to the typical local situation, the constructions and window parameters were then exchanged or adapted. The descriptions of the typical constructions were taken from data sheets from the TABULA project.

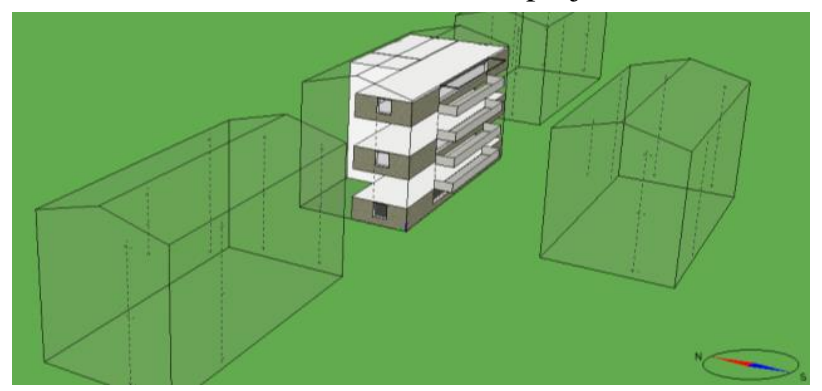

Figure 3: Standard design for building body and shading. (IDA-ICE-visualization)
The boundary conditions have been chosen as follows:

- Building body: Simple cube with balconies on south facade

- Site shading: Same cubes in distance according height $\left(45^{\circ}\right.$ angle for the ground floor)

- Orientation: N, E, S, W

- Construction elements:

- EU: according Tabula project (residential only)

- $\mathrm{CH}$ : according Swiss study and own knowhow

- Thermal bridges: default setting according construction type

- Ground properties: ISO-13370 without insulation

- Infiltration: Wind driven flow at $50 \mathrm{~Pa}$ (air change rates according EN 12831:2003 ND.5.3)

- Pressure coefficients: Semi-exposed

- Extra energy losses: none

- Internal heat loads: Equipment, lighting and occupants according SIA 20242015 (old / new)

- Zoning: Ground floor: $1 / 2 \mathrm{~S}, 1 / 4 \mathrm{~N}$; midst floor: $1 / 2 \mathrm{~S}$, $1 / 4 \mathrm{~N}$; top floor: $1 / 2 \mathrm{~S}, 1 / 4 \mathrm{~N}$; stair case (linking all zones with doors)

In addition to this, the fraction of the window area and the depth of the shadings have been adapted to typical local constructions.

For shading control and ventilation, two control macros have been developed to emulate a typical user behaviour.

- Screen drawn when: High irradiation in window pane AND high indoor temperature

- Hygienic airflow emulated with AHU without air treatment. Lower volume when cold outside, higher volume when cooling needed (night cooling).

\section{Results}

The computed results are limited to yearly energy consumption (useful energy), peak loads (max. hour values for heating and cooling) and the indoor climate comfort definition according to the standard EN-15251. This evaluation method contains four comfort levels with adaptive boundaries and is therefore convenient for this purpose in different European climate zones.

Figure 5 and Figure 6 show examples of the elaborated outputs (Excel) for Bern and Barcelona. These are always made with a relative comparison to the results with standard TMY data. While Figure 5 shows all results for one location, Figure 6 shows in a city map the results for all analysed locations applying one climate scenario.

\section{Energy consumption and thermal comfort}

In Barcelona, the current urban effect reduces the heating energy demand by $25 \%$ for current climate. (see Figure 6) Applying the RCP scenario 4.5, this reduction rises to approximately $50 \%$ for the year 2050 . The cooling energy demand lies in the city centre about 60 to $70 \%$ higher than in the surroundings. In the future, the cooling energy demand will be more than doubled in the surroundings and almost tripled in the city centre. Of course, these results assume that the indoor comfort level 
is not affected, and that the standard of the building stays maintained.

It can be observed that the heating peak load is about in the same way affected as the energy demand for the current urban effect. The future climate lowers the peak load only slightly more than the current urban effect. In other words, also in future, there will be cold periods. The situation is different for the cooling loads; the actual urban effect is not very important but in future the peak load will be about 50 to $70 \%$ higher. This finding corresponds with the important number of tropical nights in the future; the warm nights don't support the cooling and for the following day the thermal mass of the building cannot absorb the additional heat load of the day. In general, the climate change will reinforce the urban effect.

All these results suppose the existence of a cooling system with enough power, which is not defined in detail. Therefore, the comfort level is not significantly affected.

In absolute values, the heating energy demand for an old residential building in Barcelona is today, according to standard TMY, about double in comparison to the cooling energy demand. But already the current urban effect leads to the fact that heating and cooling energy demand are almost the same. In the future this will change completely, and the heating energy demand will also in the surroundings be lower than the cooling energy demand. In the city centre, the cooling energy demand will be two times higher than the heating energy demand.

Now we're looking to the results from an old residential building in Bern Figure 5. First of all, there has to be mentioned that no cooling system is assumed.

The heating energy demand is in the city centre, due to the current urban climate effect, already about 10 to $20 \%$ lower. Also, the future climate scenario RCP 4.5 does not have a very big additional influence on these criteria.

Looking at the indoor climate comfort, the current urban effect has of course an important influence on the number of occupancy hours in the best category but no significant change in the unacceptable category. This will change only in the future, where hundreds of occupancy hours will be outside the comfort limits without cooling system almost independent of the location in or around the city. In general, the urban effect in Bern shows lower impact in comparison to Barcelona.

\section{Conclusion}

This project showed that the use of urban climate data has a measurable impact on energy consumption and thermal indoor comfort. This simple fact might not be very surprising, but it is probably the first time that this aspect has been studied in a way to quantify the effect in high time and space resolution.

We understand this work also as a contribution to the current discussion about the performance gap (difference between planned and real building performance). As long as the construction regulations requires the use of non-urban climate data for the design process for buildings in urban areas, it is obvious that there occurs a difference between planned and real energy consumption or/and indoor climate. Therefore, regulations should be modified at this point, where they define which climate data must be used for which location. For instance, this becomes relevant, when the planned yearly electricity consumption for air-conditioning has to be generated onsite (which is already the case in some Swiss Cantons). The dimension of the PV-plant depends directly on the chosen climate data for the simulation.

From a more engineering point of view, the conclusions can be summarized as follows:

More accurate and realistic climate data for urban buildings are important. Above all for specific questions such as:

- Proof of concept for energy consumption for cooling systems.

- Proof of concept for solar protection and night cooling in facade design.

- Trouble shooting for problematic overheating in existing buildings.

- Improvement of long-term planning security in dimensioning for cooling systems, particularly passive systems like night free cooling, geo cooling, etc.

\section{Acknowledgement}

Climate-fit.city is developed as part of the PUCS project, which has received funding from the European Union's H2020 Research and Innovation Programme under Grant Agreement No. 73004.

\section{References}

Espinar, B., Ramírez, L., Drews, A., Beyer, H. G., Zarzalejo, L. F., Polo, J., and Martín, L., (2009). Analysis of different comparison parameters applied to solar radiation data from satellite and German radiometric stations. Solar Energy 83(1), 118-125. http://doi.org/10.1016/j.solener.2008.07.009

IEE Project TABULA (2009-2012), Typology Approach for Building Stock Energy Assessment, Information about the international research project performed from 2009 to 2012 with the support of Intelligent Energy Europe

De Ridder, K., Lauwaet, D., Maiheu, B., UrbClim: A fast urban boundary layer climate model, Urban Climate, Volume 12, (2015), Pages 21-48, ISSN 2212-0955, https://doi.org/10.1016/j.uclim.2015.01.001.

Remund, J., Müller, S.C., Kunz, S., Huguenin-Landl, B., Studer, C., Cattin, R., (2018). Meteonorm handbook. http://www.meteonorm.com/images/uploads/downlo ads/mn72_software7.2.pdf (last visited: August 28th 2018) 
Swiss Society of Engineers and Architects (2015). Standard conditions for occupation, equipment and lighting in buildings (SIA 2024)

Wilcox, S., and Marion, W., (2008). Users Manual for TMY3 Data Sets. Technical Report. doi: NREL/TP581-43156,

https://www.nrel.gov/docs/fy08osti/43156.pdf (last visited: May 9th 2018)
Settembrini, G., Domingo-Irigoyen, S., Heim, T., Jurt, D., Zakovorotnyi, A., Seerig, A., Zweifel, G., Menti, U.-P., (2017). ClimaBau - Planen angesichts des Klimawandels - The impact of climate change on the energy demand and thermal comfort in residential buildings in Switzerland until 2100

\author{
Abbreviations \\ ECMWF: European Centre for Medium-Range Weather Forecasts, Reading UK \\ ERA: ECMWF Re-Analysis \\ ERA-Interim / 5: versions of ERA \\ Netcdf: Network Common Data Form (compressed binary files) \\ NREL: National Renewable Energy Laboratory, USA \\ UrbClim: Simulation model made by VITO, Mol B \\ IPCC: Intergovernmental Panel on Climate Change \\ RCP: Representative Concentration Pathways \\ MN: Meteonorm, Software made by Meteotest, Bern CH \\ TMY: Typical Meteorological Year \\ BPS: Building Performance Simulation
}

SIA: Schweizerischer Ingenieur- und Architektenverein (swiss society of engineers and architects)

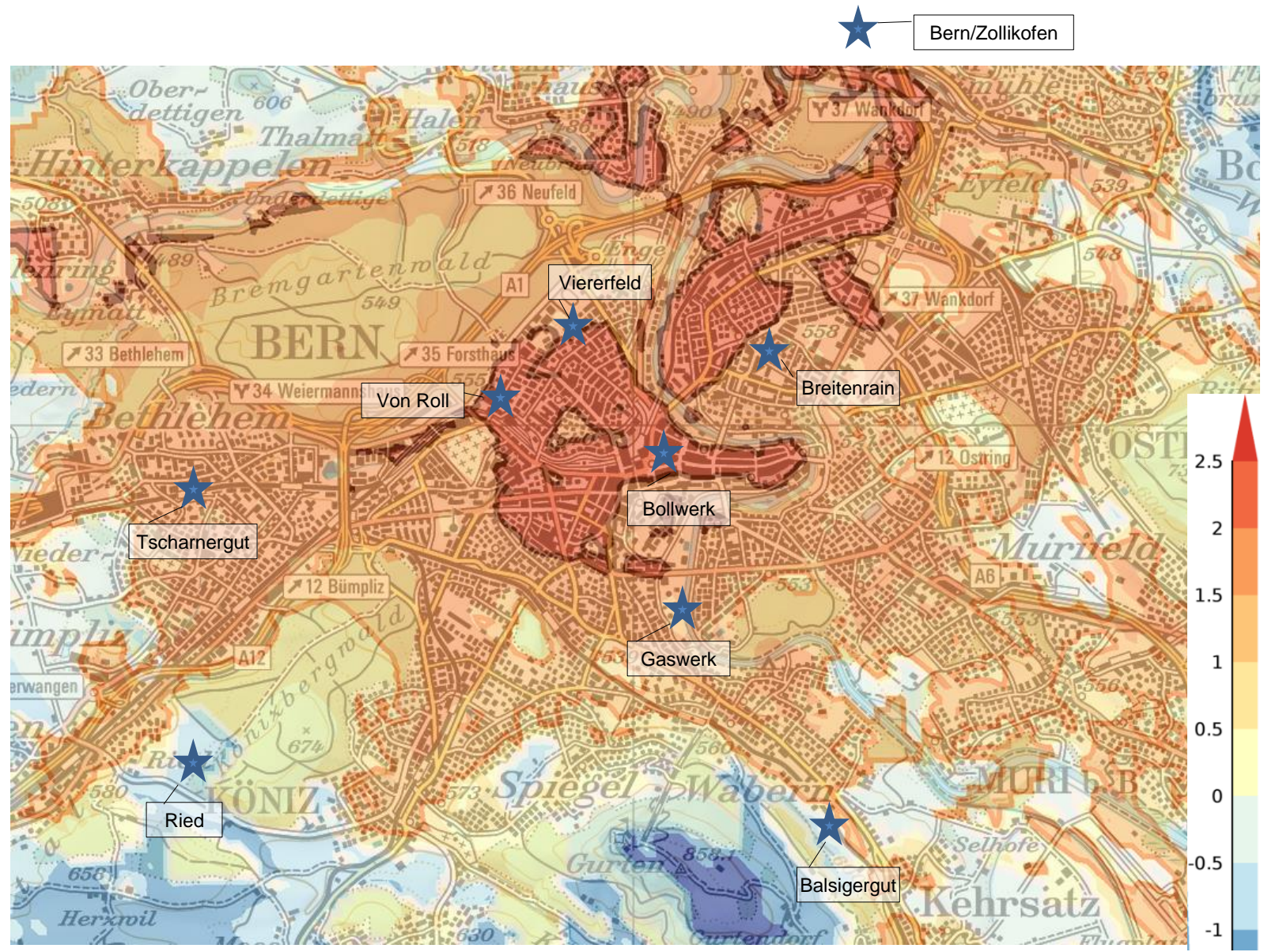

Figure 4: Average temperature difference at 04:00 UTC during clear summer nights between city and surrounding of Bern area $\left(20 \times 20 \mathrm{~km}\right.$ ) based on ERA5/UrbClim model (dark red line: $+2^{\circ} \mathrm{C}$ ). 
Table 4: Average maximum temperatures in Prague, Vienna, Rome and Barcelona in ${ }^{\circ} \mathrm{C}$

\begin{tabular}{|c|c|c|c|c|c|}
\hline Model & Centre & Airport & Add. station & $\begin{array}{c}\text { Differences } \\
\text { heat island }\end{array}$ & $\begin{array}{c}\text { Differences } \\
\text { CC (centre) }\end{array}$ \\
\hline MN 7.3 (2000-2009) & $\begin{array}{c}\text { Prague/ } \\
\text { Centre }\end{array}$ & $\begin{array}{c}\text { Prague/ } \\
\text { Airport }\end{array}$ & $\begin{array}{c}\text { Prague/ } \\
\text { Kbely }\end{array}$ & & \\
\hline MN 7.3 / RCP 4.5 (2046-55) & 38.9 & 33.1 & 31.2 & -0.2 & \\
\hline MN 7.3 / RCP 8.5 (2046-55) & 39.9 & 38.6 & 37.6 & 0.2 & 5.9 \\
\hline & $\begin{array}{c}\text { Vienna/ } \\
\text { Centre }\end{array}$ & $\begin{array}{c}\text { Vienna/ } \\
\text { Airport }\end{array}$ & $\begin{array}{c}\text { Vienna/ } \\
\text { Hohe Warte }\end{array}$ & & 7.0 \\
\hline MN 7.3 (2000-2009) & 33.9 & 35.0 & 33.1 & -2.1 & \\
\hline MN 7.3 / RCP 4.5 (2046-55) & 38.6 & 38.6 & 38.3 & 0.0 & 4.7 \\
\hline MN 7.3 / RCP 8.5 (2046-55) & 40.7 & 40.7 & 40.4 & 0.0 & 6.8 \\
\hline Roma/ & $\begin{array}{c}\text { Roma/ } \\
\text { Urbe }\end{array}$ & $\begin{array}{c}\text { Roma/ } \\
\text { Celimontana }\end{array}$ & & \\
\hline MN 7.3 (2000-2009) & 37.8 & 37.6 & 38.0 & 0.2 & \\
\hline MN 7.3 / RCP 4.5 (2046-55) & 43.3 & 43.8 & 43.5 & -0.5 & \\
\hline MN 7.3 / RCP 8.5 (2046-55) & 44.2 & 44.8 & 44.4 & -0.6 & 6.5 \\
\hline & Barcelona/ & Barcelona/ & Barcelona/ & & \\
\hline Centre & 34.7 & 32.5 & 34.7 & 2.2 & \\
\hline MN 7.3 / RCP 4.5 (2046-55) & 39.8 & 36.7 & 39.3 & 3.1 & 5.1 \\
\hline MN 7.3 / RCP 8.5 (2046-55) & 42.1 & 39.2 & 41.7 & 1.9 & 7.4 \\
\hline
\end{tabular}

Table 5: Number of tropical nights in Prague, Vienna, Rome and Barcelona.

\begin{tabular}{|c|c|c|c|c|c|}
\hline Model & Centre & Airport & Add. station & $\begin{array}{l}\text { Differences } \\
\text { heat island }\end{array}$ & $\begin{array}{l}\text { Differences } \\
\text { CC (centre) }\end{array}$ \\
\hline & $\begin{array}{c}\text { Prague/ } \\
\text { Centre }\end{array}$ & $\begin{array}{l}\text { Prague/ } \\
\text { Airport }\end{array}$ & $\begin{array}{c}\text { Prague/ } \\
\text { Kbely }\end{array}$ & & \\
\hline MN 7.3 (2000-2009) & 17 & 1 & 7 & 16 & \\
\hline MN 7.3 / RCP 4.5 (2046-55) & 36 & 29 & 27 & 7 & 19 \\
\hline \multirow[t]{2}{*}{ MN 7.3 / RCP 8.5 (2046-55) } & 41 & 30 & 35 & 11 & 24 \\
\hline & $\begin{array}{l}\text { Vienna/ } \\
\text { Centre }\end{array}$ & $\begin{array}{l}\text { Vienna/ } \\
\text { Airport }\end{array}$ & $\begin{array}{c}\text { Vienna/ } \\
\text { Hohe Warte }\end{array}$ & & \\
\hline MN 7.3 (2000-2009) & 33 & 7 & 19 & 26 & \\
\hline MN 7.3 / RCP 4.5 (2046-55) & 63 & 46 & 43 & 17 & 30 \\
\hline \multirow[t]{2}{*}{ MN 7.3 / RCP 8.5 (2046-55) } & 63 & 50 & 51 & 13 & 0 \\
\hline & $\begin{array}{l}\text { Roma/ } \\
\text { Centre }\end{array}$ & $\begin{array}{c}\text { Roma/ } \\
\text { Urbe }\end{array}$ & $\begin{array}{c}\text { Roma/ } \\
\text { Celimontana } \\
\end{array}$ & & \\
\hline MN 7.3 & 83 & 53 & 79 & 30 & \\
\hline MN 7.3 / RCP 4.5 (2046-55) & 122 & 111 & 117 & 11 & 39 \\
\hline \multirow[t]{2}{*}{ MN 7.3 / RCP 8.5 (2046-55) } & 126 & 120 & 123 & 6 & 43 \\
\hline & $\begin{array}{c}\text { Barcelona/ } \\
\text { Centre }\end{array}$ & $\begin{array}{c}\text { Barcelona/ } \\
\text { Airport }\end{array}$ & $\begin{array}{l}\text { Barcelona/ } \\
\text { Mont Juic }\end{array}$ & & \\
\hline MN 7.3 (2000-2009) & 105 & 48 & 99 & 57 & \\
\hline MN 7.3 / RCP 4.5 (2046-55) & 127 & 97 & 118 & 30 & 22 \\
\hline MN 7.3 / RCP 8.5 (2046-55) & 142 & 123 & 132 & 19 & 37 \\
\hline
\end{tabular}


Bern-Zollikofen (Location for standard TMY)

Multifamily house old (60's to 90 's)

Latitude: 46.99, Longitude: 7.468, Elevation: 551
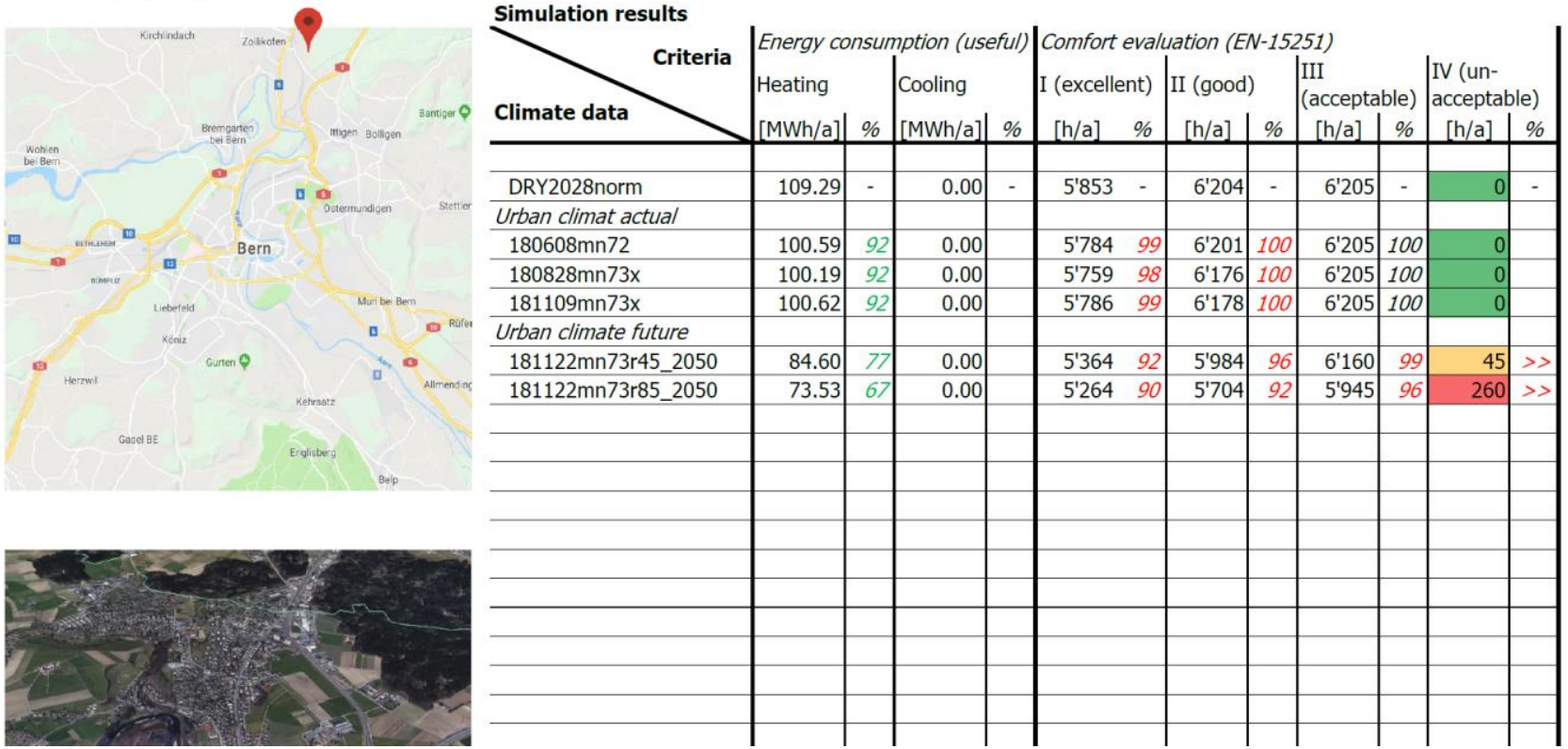

Figure 5: Analyses per location and building type with result comparison from different climate data types to standard TMY: Example for multifamily house from the 60's for Bern-Zollikofen.

MN7.3/current (2000-09)

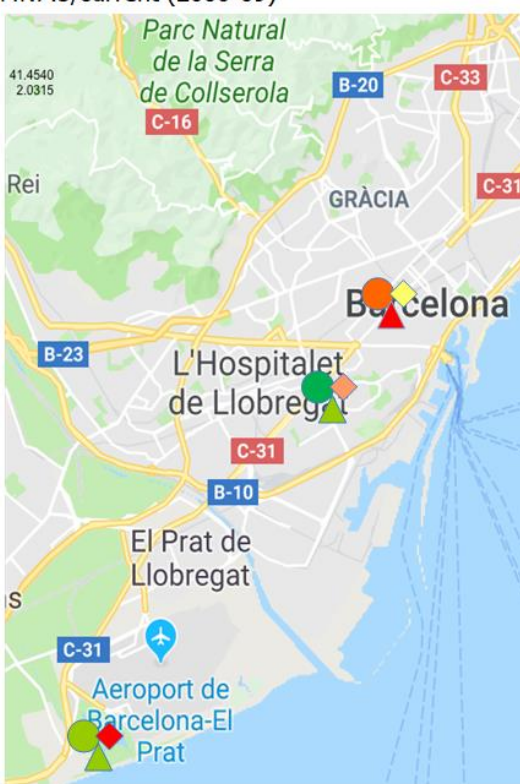

Comfort: Occupacy hours Heating energy: Relative

\begin{tabular}{|c|c|}
\hline cat. IV (unaccept.) & difference std. TMY \\
\hline$\diamond \quad 16 \ldots .20 \mathrm{~h} / \mathrm{a}$ & ○ $75 \ldots 80 \%$ \\
\hline $8 \ldots 12 \mathrm{~h} / \mathrm{a}$ & $100 \ldots 105 \%$ \\
\hline $0 \ldots 4 \mathrm{~h} / \mathrm{a}$ & $105 \ldots 110 \%$ \\
\hline
\end{tabular}

Badalona

Sant Adrià de Besòs

\section{c-31}

cooling energy: Relative difference std. TMY

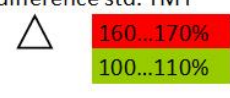

MN7.3/RCP4.5 (2046-55)

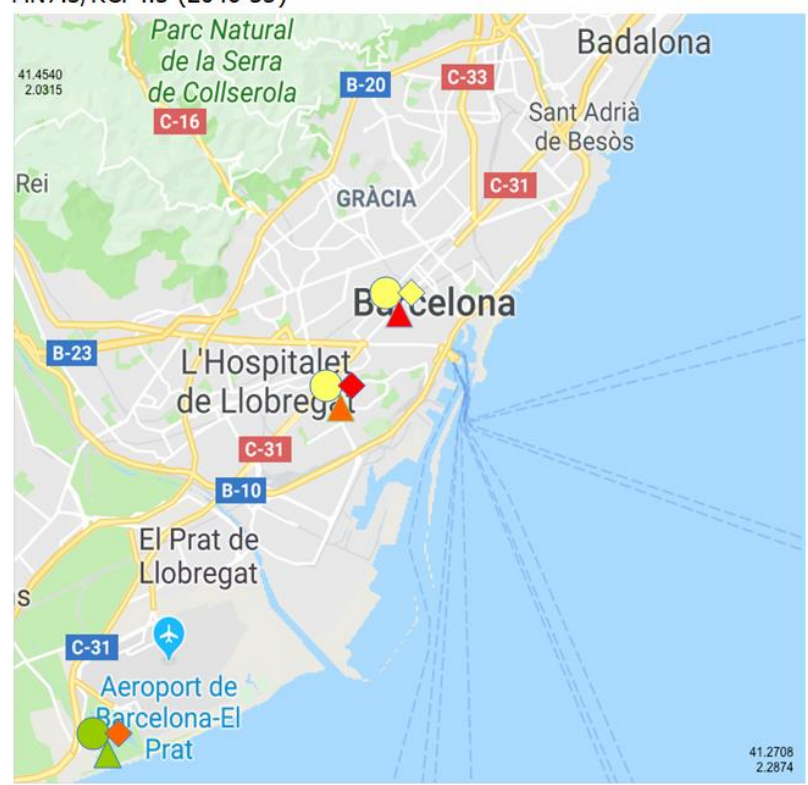

Comfort: Occupacy hours Heating energy: Relative cooling energy: Relative cat. IV (unaccept.) difference std. TMY difference std. TMY

$\diamond \begin{array}{lll}8 \ldots 10 \mathrm{~h} / \mathrm{a} \\ 6 \ldots 8 \mathrm{~h} / \mathrm{a} \\ 0 . .2 \mathrm{~h} / \mathrm{a}\end{array} \quad \bigcirc \quad \begin{aligned} & 50 \ldots 55 \% \\ & 60 \ldots 65 \%\end{aligned} \quad \Delta \begin{aligned} & 260 \ldots 270 \% \\ & 250 \ldots 260 \% \\ & 200 \ldots 210 \%\end{aligned}$

Figure 6: Analyses for the local differences per climate data and building type.: Example for old multifamily house in

Barcelona. Circle: Heating energy consumption in comparison to standard TMY; Triangle: Cooling energy consumption in comparison to standard TMY; Quadrat: Number of occupation hours per year outside the comfort zone boundaries in the most exposed zone; left: urbanized Meteonorm 7.3; right: future climate according IPCC scenario RCP 4.5. 